\title{
Effect of Surface Properties of Substrate on Structure of Closely Packed Colloidal Crystal Deposited on Fiber Surface through Dip-coating
}

\author{
Hirogaki Kazumasa ${ }^{a}{ }^{*}$, SATAKe Tomohiro ${ }^{a}$, Hirata Toyoaki $^{a}$, TABata Isao ${ }^{b}$, Hori Teruo $^{c}$ \\ a Graduate School of Engineering, University of Fukui, 3-9-1 Bunkyo, Fukui, Fukui 910-8507, Japan \\ ${ }^{\mathrm{b}}$ School of Engineering, University of Fukui, 3-9-1 Bunkyo, Fukui, Fukui 910-8507, Japan

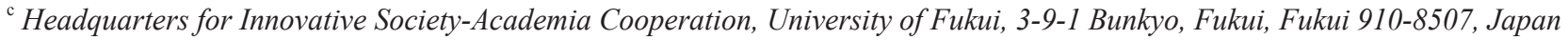

Received 3 May 2019; accepted for publication 2 September 2019

\begin{abstract}
The effects of hydrophilicity and charge of the fiber surface on the formation of closely packed colloidal crystals on the fiber was investigated. Surface-treated polyester fiber was dip-coated with water suspension of uniform-sized silica particles. Hexagonal and square arrangements were observed for the particles deposited on the fiber surface by scanning electron microscopy (SEM). The crystallinity of deposited particles was estimated with the number ratio of arranged particles to all particles in the SEM image. Colloidal crystal with mainly hexagonal arrangement was formed on the fiber with high wettability irradiated with oxygen plasma. The crystallinity was increased and the ratio of hexagonal arrangement in the crystalline region was decreased with increasing the wettability of the plasma treated fiber surface. Colloidal crystal with mainly square arrangement was formed on the fiber with cationic charge derived from the amino groups induced with a sol-gel method using 3-aminopropyltriethoxysilane (APS). Crystallinity was decreased and ratio of square arrangement in the crystalline region was decreased with increasing the amount of amino group accompanying with decreasing the wettability on the APS treated fiber surface.
\end{abstract}

Key Words : Lattice structure, Crystallinity, Wettability, Amino group, Cationic charge

\section{ディップコートにより単繊維上に形成した 堆積型コロイド結晶の構造に繊維表面の性質が及ぼす影響}

\author{
廣垣和正 ${ }^{\mathrm{a}, *}$, 佐竹智浩 ${ }^{\mathrm{a}}$, 平田豊章 ${ }^{\mathrm{a}}$, 田畑功 ${ }^{\mathrm{b}}$, 堀照夫 ${ }^{\mathrm{c}}$ \\ a 福井大学術研究院工学系部門, ${ }^{b}$ 福井大学工学部, ‘福井大学産学官連携本部
}

\section{1. 緒 言}

繊維製品の染色は，媒体に水を用いて染料を繊維へ吸着さ せることでなされ，大量の水資源とエネルギーを消費し，染 料や助剤を含む大量の廃水を生み出す産業として成立してい る。また，染色された繊維製品は，染料が光暴露下で退色を 引き起こし，その寿命に制限をもたらしている。一方で，緎 維製品の審美性は染料拈よび，布帛の設計を通して追求され てきたが，染色の長い歴史の中でそれらの限界に達してきて いると考えられる。纎維製品に対する世界的な需要は年々増
加しており, 持続可能な社会を築き, 繊維製品のさらなる審 美性を追求するには, 染料を使用しない新しい原理による繊 維の着色技術の開発が望まれている。

繊維製品の構造色による着色は，時に有害性が疑われる染 料の使用および, 大量の水資源の消費を回避する方法として, その開発が期待されている。 また, 構造色は発色する構造が 維持される限り退色しないため, 繊維製品の長寿命化に有効 であると考えられている。構造色を有する繊維を調製するい くつかの研究が報告されている [1-6]. しかしながら, これ らは繊維を紡糸する際に着色する原着法であり，最も一般的

* 連絡先 : 福井大学学術研究院工学系部門㵶維先端工学講座 910-8507 福井県福井市文京 3-9-1 E-mail : hirogaki@u-fukui.ac.jp, Tel : +81-776-27-8631, Fax : +81-776-27-8747 
な繊維製品の染色法である浸染法に代わるものではなかっ た。そこで，本研究では，ナノサイズの粒子が周期的に配置 されているオパールのコロイド結晶構造に注目した。コロイ ド結晶は, 結晶の構造周期が光の波長と同程度の大きさを 有するとき，可視光の回折により鮮やかな色を呈する。これ を利用して繊維表面上にコロイド結晶を形成することで，後 加工により繊維を構造色で着色できる。コロイド結晶により 繊維に構造色を付与するいくつかの研究が報告されており, ディップコーティング $[7]$, 電着 $[8,9]$ 抽び, 微小空間内 での自己集合 $[10,11]$ を介し, 繊維の表面上にコロイド結晶 を形成している。しかしながら, これらの研究は, 繊維上へ のコロイド結晶の形成方法を提案し, 繊維上に形成された結 晶の構造と分光反射特性を評価するのみであった。

コロイド結晶の色は，コロイド粒子のサイズと結晶の格子 構造により決まる [12]. コロイド結晶の格子構造を制御す ることは, 繊維の表面に堆積するコロイド結晶の色を制御す る上で重要な要素のひとつである。そこで，我々は，コロ イド粒子を堆積させるための最も簡単な方法のひとつである ディップコーティング法を用い，繊維上に形成されるコロイ ド結晶の構造制御について研究を進めてきた [13]. 繊維に 均一サイズのコロイド粒子水懸濁液をディップコーティング し, 次いでそれを乾燥させる。粒子は, 分散液の液膜が乾燥 する際，横毛管力を介して自己組織化することにより繊維表 面に沿って整列し，表面に形成される秩序だった粒子配列が 結晶格子の最密面として最初の層となり, そこから結晶が成 長する [14]，そのため,粒子と基材表面との相互作用により， 粒子の基材表面近傍での運動性に影響を与えることで, 結晶 構造を制御できると考えた。実際に我々は，親水性の繊維表 面に形成したコロイド結晶において，六方細密充填格子もし くは, 面心立方格子を示す六角形に並ぶ規則構造が支配的と なるのに対し, カチオン性官能基を導入した繊維表面上では, 体心立方格子もしくは，単純立方格子を示す四角形に並ぶ規 則構造が支配的となることを見出した $[13]$. そこで, 本研 究では, 繊維表面に形成されるコロイド結晶構造の繊維表面 の性質による更なる制御を目指して, 繊維表面の親水性の程 度および，繊維表面の正電荷量が繊維上のコロイド結晶の格 子構造に及ぼす影響を調べた。

\section{2. 実 験}

\section{1 試料および, 試薬}

繊維表面にコロイド結晶を形成する基材には，東洋紡株式 会社製の直径 $28 \mu \mathrm{m}$ の丸形断面ポリエステル繊維を用いた。 シリカコロイド粒子水分散液には, 直径 $300 \mathrm{~nm}$ のシリカ粒
子を $20 \mathrm{wt} \%$ 含有した水分散液である株式会社日本触媒製の シーホスターKE-W30 を購入し，そのまま用いた。分散液 の導電率と $\mathrm{pH}$ は，それぞれ， $863 \mu \mathrm{S} / \mathrm{m}, 4.65$ であった，テ トラエトキシシラン (TEOS) および, 3-アミノプロピルト リエトキシシラン (APS), エタノールは, 和光純薬工業株 式会社から一般に市販されている最も純度の高いものを購入 し，そのまま用いた

\section{2 繊維表面へのコロイド結晶の形成}

繊維表面の親水性を向上させるため, ポリエステル䋊維 にテクノアルファ株式会社製の低圧プラズマ反応器 M112967.000 を用いて照射時間を変えて酸素プラズマ処理を行っ た。またポリエステル繊維に TEOS と APS を用いたゾ ルーゲル処理を施し，纎維表面にアミノ基を導入した [15]. $\mathrm{APS} / \mathrm{TEOS}$ を合わせて $4 \mathrm{wt} \%$ および，水を $2.5 \mathrm{wt} \%$ となるよう エタノールに溶解した. APS/TEOSのモル比は, 1:1もしくは, 1:5，1:10になるよう調整した。 APS/TEOS 溶液を $30^{\circ} \mathrm{C} て ゙ ~ 45$ 分攪拌した後, ポリエステル繊維にディップコーティングし, それを風乾した後, $130^{\circ} \mathrm{C} て ゙ 30$ 分間加熱した.

上記の表面処理を施したポリエステル繊維に対してコロイ ド粒子水分散液をディップコーティングし, 次いでそれを風 乾して繊維表面にコロイド粒子を堆積させた。ディップコー ティングは, 分散液の液面に対して繊維軸方向が垂直になる よう浸漬した後，シグマ光機株式会社製の SGSP20-85(z) を 用いて $0.02 \mathrm{~mm} / \mathrm{s}$ の速度で引き上げることで行った。

\section{3 繊維表面の性質および，コロイド粒子配列の 評価}

繊維表面の元素分析は, 日本電子株式会社製のJPS9010MCY を用いて X 線光電子分光法 (XPS) により行った. 繊維表面の後退水接触角は, 協和界面科学株式会社製の CBVP A-1 を用いて Wilhelmy 法により測定した。 瀻維表面に ディップコートしたコロイド粒子の配列は，株式会社日立製 作所製の走査型電子顕微鏡 $(\mathrm{SEM}) \mathrm{S}-2600 \mathrm{H}$ により観察した。

\section{3. 結果と考察}

\section{1 表面処理を施した繊維の濡れ性と官能基の導入}

酸素プラズマ処理を施したポリエステル繊維表面の後退水 接触角とXPS により測定した $\mathrm{O} / \mathrm{C}$ を表 1 に示す。酸素プラ ズマの照射時間が長くなると共に, 繊維表面の $\mathrm{O} / \mathrm{C}$ が増加し, 水酸基やカルボキシル基など酸素由来の親水性官能基の導入

Table 1 Receding water contact angle and $\mathrm{O} / \mathrm{C}$ ratio on $\mathrm{O}_{2}$ plasma treated fiber.

\begin{tabular}{ccc}
\hline $\mathrm{O}_{2}$ plasma irradiation time $/ \mathrm{s}$ & Receding water contact angle $/{ }^{\circ}$ & $\mathrm{O} / \mathrm{C}$ \\
\hline 30 & 62 & 0.604 \\
60 & 55 & 0.772 \\
300 & 45 & 0.762 \\
\hline
\end{tabular}


Table 2 Receding water contact angle and N/C ratio on APS treated fiber.

\begin{tabular}{ccc}
\hline APS : TEOS & Receding water contact angle $/{ }^{\circ}$ & N/C \\
\hline $1: 1$ & 52 & 0.106 \\
$1: 5$ & 41 & 0.038 \\
$1: 10$ & 37 & 0.027 \\
\hline
\end{tabular}

が示唆され [15], これに伴い後退水接触角の低下がみられた. APS 処理した繊維表面の後退接触角とXPS により測定した N/C を表 2 に示す。XPS 測定において検出された $\mathrm{N}$ は結合工 ネルギーからアミノ基に由来することが示唆された。ゾル ゲル処理における APS の TEOS に対する比率が高くなると繊 維表面の $\mathrm{N} / \mathrm{C}$ が増加し，アミノ基の導入量が増加した。一方 で，APSの TEOS に対する比率が低くなると，後退接触角の 低下がみられた。繊維表面に被服される TEOSの割合が高く なり, TEOS 由来の水酸基の導入量が増加したためと考えた.

\section{2 コロイド結晶の構造に及ぼす繊維表面の影響}

コロイド粒子を堆積したポリエステル繊維の代表的な SEM 像を図 1 に示す。SEM像から, 粒子の堆積層には無秩序に 粒子が存在する領域に加えて，4つの粒子を単位として四角 形に配列した規則構造をとる領域および，7つの粒子を単位 として六角形に配列した規則構造をとる領域が観察された (図中に点線で例示)。規則構造をとる領域を結晶部, 無秩序 な領域を非晶部とし，SEM 像に占めるそれぞれの粒子数の 比から結晶化度を求めた。粒子は，四角形の規則構造をとる 領域では単純立方格子 (SC) もしくは，体心立方格子 (BCC) を形成しており，六角形の規則構造をとる領域では面心立方 格子 (FCC) もしくは, 六方最密充填格子 (HCP) を形成して いると予想される。筒状の繊維を用いたが，コロイド粒子 の配列に異方性は見られなかった。

酸素プラズマ処理繊維の濡れ性が繊維表面に堆積したコロ イド粒子の結晶構造に及ぼす影響を図 2 に示す。酸素プラズ マ処理繊維の表面に形成されたコロイド結晶は，六角形の規
則構造をとる割合が高かった，繊維表面の濡れ性が高くなる と共に結晶化度が増加したが，六角形の規則構造をとる割合 が低下し，格子構造の不均化を招いた。一般に不均一核生成 において，基材表面の濡れ性の向上により結晶核の生成速度 が増加することが知られている。纎維表面の濡れ性が増すこ とで, 結晶化度が増加する一方, 準安定な結晶格子の形成も 引き起こしやすくなり，規則配列の不均化が大きくなったと 考えた.APS と TEOS の比率を代えてアミノ基を導入した繊 維の N/C 比と濡れ性が繊維表面に堆積したコロイド粒子の 結晶構造に及ぼす影響を図 3 に示す。図 2 と 3 の比較から, APS 処理繊維表面に形成されたコロイド結晶は, 酸素プラズ マ処理繊維表面に形成されたものと比べて、結晶化度が低く、 また四角形の規則構造をとる割合が高く，四角形の規則構造 が結晶領域の大半を占めた。シリカ粒子は水中でシラノール 基の解離により負に帯電しており, アミノ基により正に帯電 したAPS 処理緎維表面では静電的な相互作用により運動が 束縛される，表面で粒子がより自由に運動できる酸素プラズ マ照射繊維では, APS 処理繊維と比べて, 堆積したコロイド 粒子の結晶化度が高くなり，より安定で密な格子構造をとる 割合が高くなったと考えた [13]。繊維表面のアミノ基由来 の Nの量が増加すると結晶化度が低下し，六角形の規則構造 をとる領域の比率が増加した． N の増加と共に繊維表面の濡 れ性も低下しており, APS 処理䋊維においても酸素プラズマ 処理繊維と同様に，濡れ性の向上に伴い結晶化度が増加する と共に, 結晶領域において四角形の規則構造が占める割合が 増加する傾向を見出した。
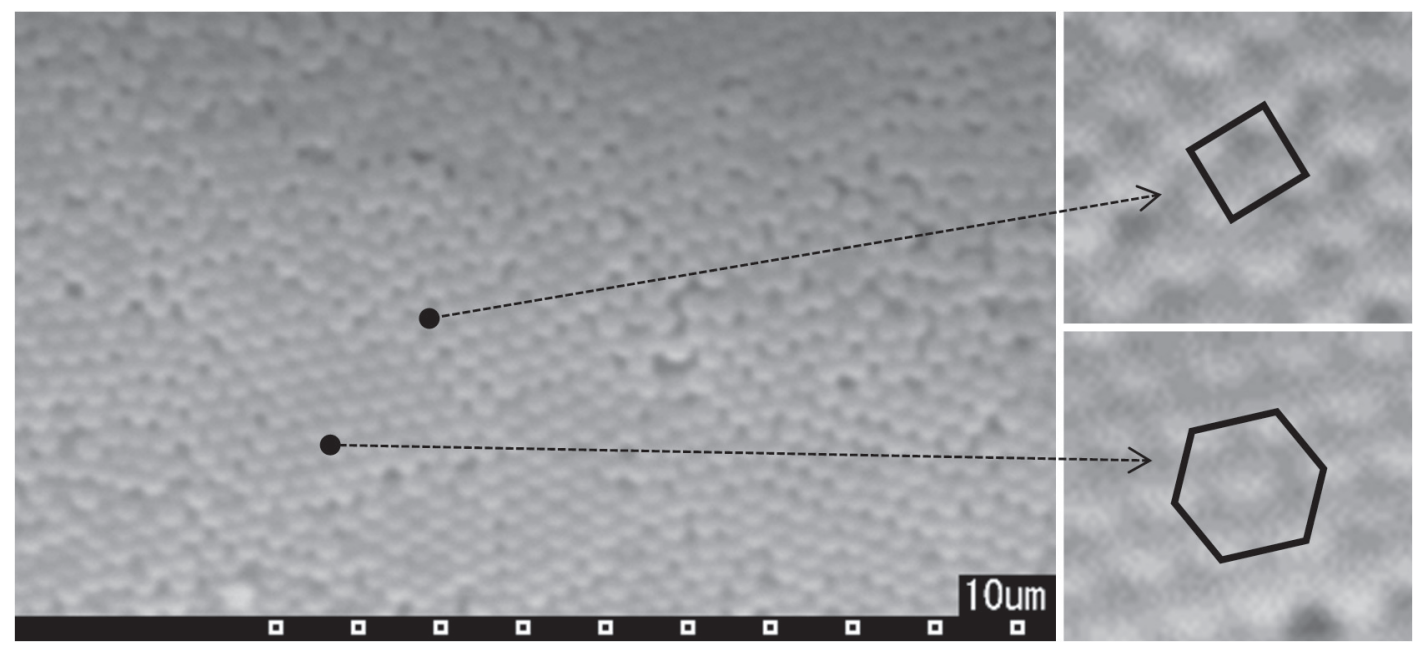

Fig. 1 Typical SEM image of colloids dip-coated on fiber (horizontal direction in image is along fiber axis direction). 


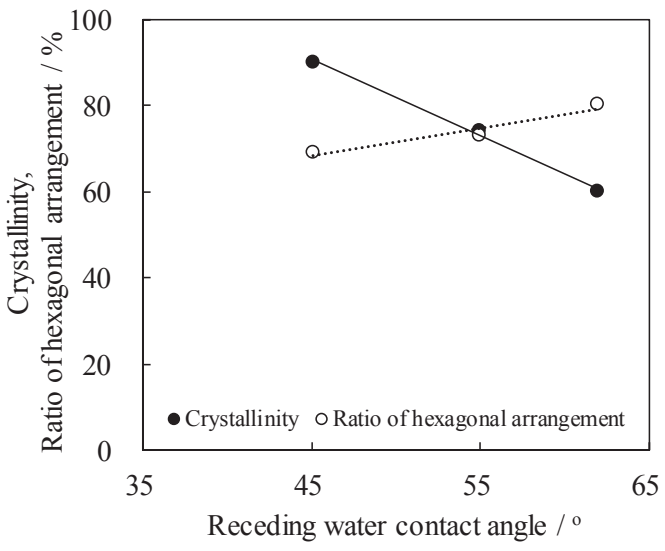

Fig. 2 Crystallinity and ratio of hexagonal arrangement in crystalline region of colloid particles deposited on $\mathrm{O}_{2}$ plasma treated fiber.

\section{4. 結 言}

緎維上のコロイド結晶の形成における繊維表面の親水性お よび，電荷の効果を調べた。表面処理したポリエステル繊 維に直径 $300 \mathrm{~nm}$ の粒径が均一なシリカ粒子をディップコー ティングした。酸素プラズマを照射した濡れ性が高い緘維表 面では，粒子の運動が自由になり最も安定な構造である六角 形の規則配列（FCCもしくは，HCP）を主とした結晶を形成 し，高い結晶化度が得られた。繊維表面の濡れ性が高くなる と共に結晶化度も高くなる一方で，六角形の規則構造をとる 割合が低下した。APS 処理によりアミノ基を導入した瀻維表 面では，水分散液中で正に帯電する繊維表面と負に帯電する シリカコロイド粒子間で静電相互作用が働き, 粒子の運動が 束縛されることにより準安定な構造である四角形の規則構造 (SCもしくは，BCC）を主とした結晶を形成した。繊維表面 のアミノ基の導入量が増え, 濡れ性が低下すると共に, 結晶 化度が低下し，六角形に配列する粒子の割合が高くなった。 以上の結果から, 緎維表面の性質によりコロイド粒子の堆積 構造を変化できた。表面の特性によりコロイド結晶の構造を 制御し, 構造に由来して色が変化することから, 調色の可能 性が示唆された。繊維上に形成されたコロイド粒子堆積層の 厚みや，堆積層の表面と繊維界面における粒子集合状態の関 係は，構造発色性材料の性質を理解する上で重要となる。今 後，これらを明らかにし，異なる性質を持つ繊維表面からの コロイド粒子堆積構造の形成過程を明らかにすると共に，そ の構造と光学特性の関係を明らかにしていく，コロイド結晶 は一般的な結晶と比べて弾性率が極めて小さく脆い. そのた め, コロイド結晶を形成する粒子間にモノマーを浸透させ重 合することで，高分子材料中にコロイド結晶を固定する試み が行われており，例えばエラストマーで結晶構造を維持した まま構造を安定化できることが報告されている $[16,17]$ ，本 研究の結果は, 繊維表面でのコロイド結晶の形成・構造制御 による調色を経て, その構造を固定する新たな着色法の開発 に繋がると期待される。

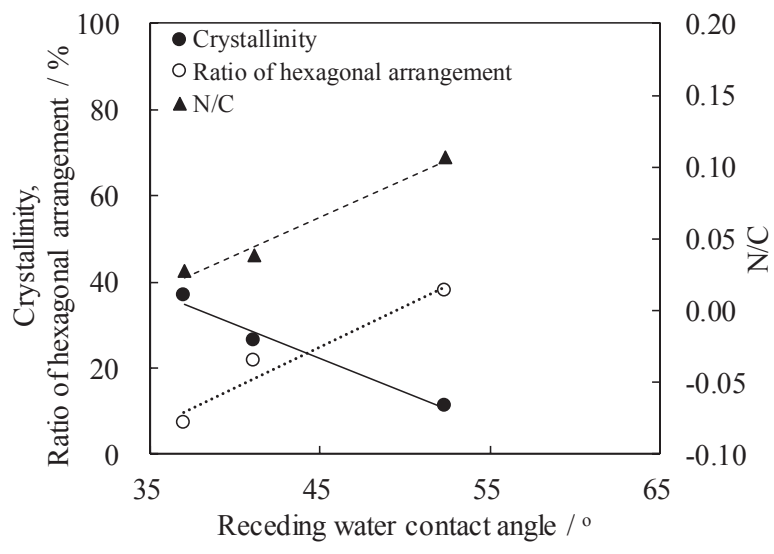

Fig. 3 Crystallinity and ratio of hexagonal arrangement in crystalline region of colloid particles deposited on APS treated fiber.

\section{謝 辞}

本研究の一部は, 公益財団法人スガウェザリング技術振興 財団第 33 回研究助成を受けて実施された。

\section{References}

[1] Tabata H (2003) Sen'i Gakkaishi, 59, 55-58. https://doi. org/10.2115/fiber.59.P_55

[2] Finlayson CE, Goddard C, Papachristodoulou E, Snoswell RED, Kontogeorgos A, Spahn P, Hellmann GP, Hess O, Baumberg JJ (2011) Optics Express, 19, 3144-3154. https:// doi.org/10.1364/OE.19.003144

[3] Kim S-H, Hwang H, Yang S-M (2012) Angewandte Chemie International Edition, 51, 3601-3605. https://doi. org/10.1002/anie.201108324

[4] Kolle M, Lethbridge A, Kreysing M, Baumberg JJ, Aizenberg J, Vukusic P (2013) Advanced Materials, 25, 2239-2245. https://doi.org/10.1002/adma.201203529

[5] Yuan W, Zhou N, Shi L, Zhang KQ (2015) Applied Materials and Interfaces, 7, 14064-14071. https://doi.org/10.1021/ acsami. 5 b03289

[6] Shang S, Liu Z, Zhang Q, Wang H, Li Y (2015) Journal of Materials Chemistry A, 3, 11093-11097. https://doi. org/10.1039/C5TA00775E

[7] Yan H, Zhao X, Qiao C, Zhen Z, Xiong G, Li Q, Wang M, Han D (2012) Applied Physics B, 107, 91-95. https://doi. org/10.1007/s00340-011-4863-y

[8] Liu Z, Zhang Q, Wang H, Li Y (2013) Nanoscale, 5, 69176922. https://doi.org/10.1039/C3NR01766D

[9] Zhou N, Zhang A, Shi L, Zhang K-Q (2013) Macro Letters, 2, 116-120. https://doi.org/10.1021/mz300517n

[10] Liu Z, Zhang Q, Wang H, Li Y (2011) Chemical Communications, 47, 12801-12803. https://doi. org/10.1039/C1CC15588A

[11] Liu Z, Zhang Q, Wang H, Li Y (2013) Journal of Colloid 
and Interface Science, 406, 18-23. https://doi.org/10.1016/ j.jcis.2013.05.057

[12] Takeoka Y, Watanabe M (2003) Langmuir, 19, 9554-9557. https://doi.org/10.1021/la0344175

[13] Hirogaki K, Nakamura D, Sekiguchi K, Satake T, Tabata I (2018) Coloration Technology, 134, 271-274. https://doi. org/10.1111/cote. 12349

[14] Sakai T, Takeoka Y, Seki T, Yoshida R (2007) Langmuir, 23,
8651-8654. https://doi.org/10.1021/la700448t

[15] Mizuno M, Takagi T, Hirogaki K, Hori T (2012) Sen'i Gakkaishi, 68, 88-92. https://doi.org/10.2115/fiber.68.88

[16] (2013) Future Materials, 4, 12.

[17] Ito T, Katsura C, Sugimoto H, Nakanishi E, Inomata K (2013) Langmuir, 29, 13951-13957. https://doi.org/10.1021/ la4030266 